\title{
Isolation of an extracellular protease gene of Erwinia carotovora subsp. carotovora strain SCC3193 by transposon mutagenesis and the role of protease in phytopathogenicity
}

\author{
Reet Marits, Viia Kõiv, Eve Laasik and Andres Mäe \\ Author for correspondence: Andres Mäe. Tel: +3727375014 . Fax: +3727420286. \\ e-mail : amae(atamm.ebc.ee
}

Department of Genetics, Institute of Molecular and Cell Biology, Tartu University, Estonian Biocentre, Riia 23, Tartu EE51010, Estonia
Using mini-Tn5 $\mathrm{Cm}^{\mathrm{R}}::$ gusA, a transposon that allows transcriptional fusions to a promoterless $\beta$-glucuronidase gene, a mutant of Erwinia carotovora subsp. carotovora SCC3193 deficient in extracellular protease production and soft-rot pathogenicity in plants was isolated. The mutant, designated SCC6004, produced normal levels of pectate lyase, polygalacturonase and cellulase. The region of the transposon insertion was partially sequenced to permit the design of specific oligonucleotide primers to amplify a $2 \cdot 7 \mathbf{~ k b ~ C l a l ~ f r a g m e n t ~}$ from E. carotovora subsp. carotovora SCC3193. The DNA sequence of the cloned fragment contained two complete and one partial ORFs. One of the complete ORFs (ORF1) was designated prtW and encodes a secreted protease. The deduced amino acid sequence of PrtW showed a high overall identity of $60-66 \%$ to the previously described Erwinia chrysanthemi proteases, but no homology to other proteases isolated from different $E$. carotovora strains. Downstream from ORF1, a further complete ORF (ORF2) and a partial ORF (ORF3) were found, with deduced peptide sequences that have significant similarity to the Inh and PrtD proteins, respectively, from E. chrysanthemi, which are involved in protease secretion. Gene fusion to the gusA reporter was employed to characterize the regulation of prtW. The prtW gene was found to be strongly induced in the presence of plant extracts. The mutant exhibited reduced virulence, suggesting that PrtW enhances the ability of strain SCC3193 to macerate plant tissue.

Keywords: Erwinia, transposon mutagenesis, protease gene, pathogenicity

\section{INTRODUCTION}

The interaction between plant and pathogen is a dynamic process involving signal exchange between interacting organisms. It is conceivable that the different extracellular enzymes produced by certain plant pathogens have different roles in pathogenesis, for example are required at different stages of infection or in different host plant tissues. The central role of pectolytic enzymes in Erwinia soft rot is well documented. This has been demonstrated by isolation of avirulent mutants

\footnotetext{
Abbreviations: pNP, p-nitrophenol; X-GICA, 5-bromo-4-chloro-3-indolyl $\beta$-D-glucuronic acid.

The GenBank accession number for the sequence determined in this work is AF141295.
}

of Erwinia carotovora that are defective either in enzyme production (Murata et al., 1991; Pirhonen et al., 1991, 1993; Jones et al., 1993; Liu et al., 1993) or secretion (Pirhonen et al., 1991). In Erwinia chrysanthemi, differential expression of genes for pectate lyases has been observed in different hosts (Beaulieu et al., 1993) and even in different tissues of the same host (Lojkowska et al., 1993). Some evidence suggests that in soft-rot erwinias some genes which are involved in virulence are activated only by compounds of plant origin. Kelemu $\&$ Collmer (1993) and McMillan et al. (1994) have shown that several novel isoenzymes of Pel (pectate lyase) and Peh (polygalacturonase) were induced when soft-rot erwinias were grown in the presence of methoxylated pectin or cell-wall extract. In E. carotovora subsp. carotovora, induction of pectic enzymes involves cellwall degradation products (Yang et al., 1992). Similarly, 
Mäe et al. (1995) suggested that two distinct cellulases of E. carotovora are differentially controlled by plantderived factors.

In addition to pectolytic enzymes and cellulases, several erwinias and pseudomonads causing soft rot secrete proteases. Among soft-rot pseudomonads, extracellular protease production correlates more strongly with the ability to macerate plant tissue than does pectolytic enzyme production (Sands \& Hankin, 1975). Relatively little work has previously been done to characterize the role of proteases in bacterial soft-rot disease caused by erwinias. However, several studies have been conducted to investigate the biochemical properties and secretion of proteases in plant-pathogenic bacteria (Delepelaire \& Wandersman, 1989; Wandersman, 1989; Letoffe et al., 1989, 1990; Dahler et al., 1990). Extracellular proteases produced by plant pathogens have been postulated to provide either amino acids for the biosynthesis of microbial proteins or to degrade host proteins associated with resistance mechanisms (Heilbronn \& Lyon, 1990; Kyöstiö et al., 1991). Although there is little experimental evidence concerning either of these possible functions, Heilbronn et al. (1995) showed in vitro degradation of potato lectins by a protease from the potato pathogen E. carotovora.

As plant molecules can act as recognition factors for invading bacteria, we attempted to identify host-inducible genes, expecting that these genes would be involved in virulence functions. Mutagenesis was done with a mini-Tn $5 \mathrm{Cm}^{\mathrm{R}}:: g u s A$ transposon which carries a promoterless selectable reporter gene, the $\beta$ glucuronidase gene. Upon insertion, the truncated gene can fuse to E. carotovora subsp. carotovora promoters. Mutants containing insertions in plant-inducible genes were selected on minimal medium plates containing plant extract. This method permits both the identification of E. carotovora subsp. carotovora promoters inducible by host factors present in plant extracts and the isolation in a single step of mutants which can be directly tested for virulence on plants.

Using this method, we identified several plant-inducible genes and showed that some of them are involved in virulence functions. One of the mutants produced undetectable levels of protease under all conditions tested. Plant infection studies showed that the proteasedeficient mutant was less virulent than the wild-type parent on tobacco and potato tubers. The insertion in this mutant mapped in a genomic cluster involved in protease production. The deduced translated product of this ORF was designated PrtW. This report describes the isolation and characterization of the $p r t W$ gene.

\section{METHODS}

Bacterial strains, plasmids, media and culture conditions. Bacterial strains and plasmids used or constructed in this study are described in Table 1 . Unless otherwise stated, Escherichia coli strains were grown at $37^{\circ} \mathrm{C}$ and E. carotovora was grown at $28^{\circ} \mathrm{C}$ in L broth (Miller, 1972) or in M9 minimal medium (Maniatis et al., 1982) supplemented with trace elements (Bauchop \& Elsden, 1960). When required, media were supplemented with $0.4 \%(\mathrm{w} / \mathrm{v})$ glycerol, X-GlcA (5bromo-4-chloro-3-indolyl $\beta$-D-glucuronic acid) at a concentration of $50 \mu \mathrm{g} \mathrm{ml}^{-1}$ and with antibiotics at the following concentrations $\left(\mu \mathrm{g} \mathrm{m}^{-1}\right)$ : ampicillin, 150; kanamycin, 25 ; and chloramphenicol, 25. Celery extract was prepared according to Murata et al. (1991). Crude potato extract was obtained by crushing potato tubers. The juice was clarified by centrifugation at $10000 \mathrm{~g}$ and subsequent filtration on membranes of decreasing porosity. The extract was sterilized by filtration through a $0 \cdot 22 \mu \mathrm{m}$ porosity membrane and stored at $-70^{\circ} \mathrm{C}$ in aliquots for several months. Protease activity was detected on $\mathrm{L}$ agar plates containing $5 \%$ skim milk.

DNA transformation, isolation, analysis and manipulation. Escherichia coli cells were transformed by the $\mathrm{CaCl}_{2}$ method (Maniatis et al., 1982). Plasmids were introduced into $E$. carotovora by electroporation (Ausubel et al., 1987; Py et al., 1991). Plasmid preparations and isolation of restriction fragments from low-melting-point agarose gels were performed with Qiagen plasmid kits. DNA cleavage by restriction endonucleases and agarose gel electrophoresis were performed as described by Maniatis et al. (1982).

Construction of a promoter-probe transposon. The promoterless gusA gene from pGUS102 was inserted as a $1.8 \mathrm{~kb} E c o$ RI fragment into $\mathrm{pUT} / \mathrm{mini}-\mathrm{Tn} 5 \mathrm{Cm}^{\mathrm{R}}$. The plasmid in which the gusA gene was oriented so that it would be transcribed from the outside end of pUT/mini-Tn $5 \mathrm{Cm}^{\mathrm{R}}$ was designated pPRG (Table 1).

Introduction of transposons into $E$. carotovora subsp. carotovora strain SCC3193. E. carotovora subsp. carotovora strain SCC3193 was used as a recipient. Biparental matings were carried out as described by de Lorenzo et al. (1990) on M9 minimal medium at $28^{\circ} \mathrm{C}$ using Escherichia coli S17-1 $\lambda$-pir containing a suicide vector $\mathrm{pUT} / \mathrm{mini}-\mathrm{Tn} 5 \mathrm{Cm}^{\mathrm{R}}:: \mathrm{gus} A$ as the donor strain. Transconjugants were selected on M9 minimal medium (using $0.4 \%$ glycerol as carbon source for the recipient strain) plus chloramphenicol to select for insertion of the transposon. S17-1 $\lambda$-pir cannot grow on this medium because it is auxotrophic for proline.

DNA sequence determination. The mutated $p r t W$ gene was cloned by cutting chromosomal DNA from the protease transposon mutant SCC6004 with ClaI, ligating this DNA to ClaI-digested pBluescript SK( +), followed by transformation into Escherichia coli strain DH5 2 . The plasmid obtained was named pROT1. The DNA flanking the transposon was then partially sequenced by the dideoxy method of Sanger et al. (1977), using the Sequenase System version II of US Biochemicals and $\left[{ }^{35} \mathrm{~S}\right] \mathrm{dATP} \alpha \mathrm{S}$ with oligonucleotide primers annealing to the vector DNA and synthetic oligonucleotide primers designed from the sequences obtained. The corresponding genomic fragment was amplified from the wild-type strain SCC3193 by PCR using as primers: ProS, 5'-AATCGATAATAAAAATTAGTCATCATTACC- $3^{\prime}$ and Pro2, 5'-GCTACATCACACGATAAAATCGGTTG-3'. All PCR amplifications were performed with the proof-reading DNA polymerase $P w o$ (Boehringer Mannheim). The resulting $2.7 \mathrm{~kb}$ PCR fragment containing the $p r t \mathrm{~W}$ gene and flanking regions was ligated to $S m a$-digested pBluescript $\mathrm{SK}(+)$ to create plasmid pROT2. The complete sequence of both strands was determined. The data were analysed by the PC/GENE program.

Enzyme assays. $\beta$-Glucuronidase activity was assayed by using $p$-nitrophenyl $\beta$-D-glucuronide as substrate (Novel et al., 
Table 1. Bacterial strains and plasmids

\begin{tabular}{|c|c|c|}
\hline Strain or plasmid & Relevant characteristics & Source or reference \\
\hline \multicolumn{3}{|l|}{ Bacterial strains } \\
\hline \multicolumn{3}{|l|}{ Escherichia coli } \\
\hline $\mathrm{DH} 5 \alpha$ & & BRL \\
\hline S17-1 $\lambda$-pir & $\begin{array}{l}\mathrm{Km}^{\mathrm{R}} \mathrm{Sm}^{\mathrm{R}}, \text { recA thi pro } h s d R^{-} R^{+} \mathrm{Rp} 4: 2- \\
\mathrm{Tc}^{\mathrm{R}}: \mathrm{Mu}: \mathrm{Km}^{\mathrm{R}} \mathrm{Tn} 7 \lambda \text {-pir }\end{array}$ & de Lorenzo et al. (1990) \\
\hline \multicolumn{3}{|c|}{ Erwinia carotovora subsp. carotovora } \\
\hline SCC3193 & Wild-type & Pirhonen et al. $\langle 1991\rangle$ \\
\hline SCC 3009 & $\exp S:: \mathrm{Km}^{\mathrm{R}}$ & Pirhonen et al. (1991) \\
\hline SCC3060 & $\exp A:: \mathrm{Km}^{\mathrm{R}}$ & Pirhonen et al. (1991) \\
\hline SCC3065 & $\operatorname{expl}:: \operatorname{Tn} 903$ & Pirhonen et al. (1991) \\
\hline SCC6004 & prtW::Tn5-gusA & This study \\
\hline \multicolumn{3}{|l|}{ Plasmids } \\
\hline pBluescript SK(+) & Cloning vector $\left(A p^{R}\right)$ & Stratagene \\
\hline $\mathrm{pUT} / \mathrm{mini}-\operatorname{Tn} 5 \mathrm{Cm}^{\mathrm{R}}$ & & de Lorenzo et al. (1990) \\
\hline pGUS102 & $\begin{array}{l}\mathrm{Ap}^{\mathrm{R}} \mathrm{Tc}^{\mathrm{R}} \text {, promoterless } 1.8 \mathrm{~kb} \text { gus } A \text { gene as } \\
\text { an EcoRI fragment in } \mathrm{pBR} 322\end{array}$ & $\begin{array}{l}\text { A. Eriksson, Swedish } \\
\text { University of Agricultural } \\
\text { Sciences, Uppsala, Sweden }\end{array}$ \\
\hline pPRG & $\begin{array}{l}\mathrm{Ap}^{\mathrm{R}} \mathrm{Cm}^{\mathrm{R}} ; \operatorname{mini} \operatorname{Tn} 5 \mathrm{Cm}^{\mathrm{R}}:: g u s A \\
\text { (promoterless gusA for transcriptional } \\
\text { fusions) in pUT } / \text { mini-Tn } 5 \mathrm{Cm}^{\mathrm{R}}\end{array}$ & This study \\
\hline pROT1 & $\begin{array}{l}\text { Ap }{ }^{\mathrm{R}}, 2 \cdot 7 \mathrm{~kb} \text { ClaI fragment from } \mathrm{SCC} 6004 \\
\text { containing prtW with a } \\
\text { miniTn } 5 \mathrm{Cm}^{\mathrm{R}}:: \text { gus A cloned into } \\
\text { pBluescript } \mathrm{SK}(+)\end{array}$ & This study \\
\hline pROT2 & $\begin{array}{l}\mathrm{Ap}^{\mathrm{R}}, 2.7 \mathrm{~kb} \text { PCR fragment from SCC } 3193 \\
\text { containing prtW cloned into pBluescript } \\
\mathrm{SK}(+)\end{array}$ & This study \\
\hline
\end{tabular}

1974). The degradation product, $p$-nitrophenol ( $\mathrm{pNP}$ ), was detected at $405 \mathrm{~nm}$ and $\beta$-glucuronidase-specific activities were expressed as nmol pNP liberated $\min ^{-1}\left(\mathrm{OD}_{600} \text { unit }\right)^{-1}$.

Protease was assayed by the azocasein method (Ji et al., 1987), and one unit was defined as the amount of enzyme that produced an increase in $A_{436}$ of $1.0 \mathrm{~h}^{-1}$ at $30^{\circ} \mathrm{C}$.

The activities of polygalacturonase, pectate lyase and cellulase were assayed as described previously (Pirhonen et al., 1991).

Pathogenicity test. Tubers were washed and immersed twice for $20 \mathrm{~min}$ in $5 \%$ sodium hypochlorite, rinsed in sterile deionized water and air-dried under a laminar hood. Maceration of potato was tested by injection by pipette tip of $5 \mu \mathrm{l}$ ontaining $10^{6}$ c.f.u. bacteria from an overnight culture into the tubers. The inoculated tubers were incubated at $28^{\circ} \mathrm{C}$ under $100 \%$ humidity and the development of symptoms was evaluated after $48 \mathrm{~h}$ by measuring the weight of the macerated tissue. Each value is the mean of five inoculations.

The virulence of the E. carotovora subsp. carotovora strains to tobacco (Nicotiana tabacum cv. Samsun) seedlings was tested. Two- to four-week-old tobacco seedlings grown on 24-well tissue culture plates were locally inoculated with $10^{6}$ c.f.u. bacteria from an overnight culture. The leaves were punctured by needle and $1 \mu$ lof bacterial suspension was applied to the leaf. One leaf per well was inoculated. The inoculated plants were incubated at $28{ }^{\circ} \mathrm{C}$ under $100 \%$ humidity. The development of disease symptoms (tissue maceration) was followed for $12-66 \mathrm{~h}$.

\section{RESULTS}

\section{Isolation of plant-inducible mutants by mini- Tn $5 \mathrm{Cm}^{\mathrm{R}}$ :: gusA mutagenesis}

E. carotovora subsp. carotovora SCC3193 was mutagenized by random insertion of the miniTn $5 \mathrm{Cm}^{\mathrm{R}}:: g u s A$ transposon. A pool of insertion mutants was tested in parallel on X-GlcA-containing plates with and without plant extract added. Mutants containing insertions in plant-inducible genes were identified by a blue colour on M9 minimal medium/ glycerol plates supplemented with X-GlcA in the presence of plant extract. Colonies which were blue on both plates were considered to have insertions in constitutively expressed genes. Of 6000 colonies tested only 12 showed induction, at levels between $1 \cdot 3-$ and 17 fold. One of the isolated mutants, designated SCC6004, did not show the normal halo around the colony on skimmed milk agar but produced normal levels of pectate lyase, polygalacturonase and cellulase and was selected for further study.

\section{Isolation of the prtW gene}

To characterize the mutated locus and gain an insight into its function, the entire nucleotide sequence of the $2.7 \mathrm{~kb}$ genomic fragment originating from E. carotovora 


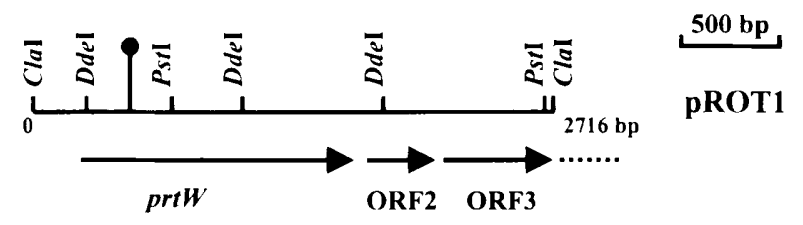

Fig. 1. Localization of the mini-transposon $\operatorname{Tn} 5 \mathrm{Cm}^{R}:: g u s A$ in prtW mutant SCC6004; the $2.7 \mathrm{~kb}$ insert in pBluescript SK( + ) is shown. The site of insertion of the transposon leading to the fusion with the protease gene prtW is marked with a filled circle. The map also shows the localization and transcription direction of ORF2 whose deduced polypeptide sequence shows similarity to the inhibitory gene inh from $E$. chrysanthemi, and the 5 ' part of ORF3 whose deduced polypeptide sequence shows similarity to prtD from $E$. chrysanthemi. Arrows indicate the location of prtW, ORF2 and ORF3 coding regions and the direction of transcription.

subsp. carotovora SCC 3193 in pROT2 was determined. This fragment was shown to contain three ORFs, two complete and one partial (Fig. 1). The first ORF, corresponding to the prtW gene, consists of 1421 nucleotides. The deduced amino acid sequence of $\mathrm{PrtW}$ would give a polypeptide with calculated molecular mass of $51 \mathrm{kDa}$. A second ORF was found downstream, apparently organized in the same operon. The deduced polypeptide sequence shows similarity to the inh gene product from E. chrysanthemi (Letoffe et al., 1989). Further downstream of these two ORFs, we found the $5^{\prime}$ part of a third ORF. The deduced polypeptide sequence has high homology to protease secretion protein prtD from E. chrysanthemi (Letoffe et al., 1990).

\section{Sequence analysis of the prtW gene}

A search of the protein databases with the deduced amino acid sequence of the PrtW polypeptide showed significant similarity to proteases PrtB, PrtC, PrtA and PrtG from E. chrysanthemi (Delepelaire \& Wandersman, 1989; Dahler et al., 1990; Ghigo \& Wandersman, $1992 \mathrm{a}, \mathrm{b})$. The predicted sequence of $\operatorname{PrtW}$ is $66.2 \%$ identical to PrtC, $65.5 \%$ identical to PrtA and $65.8 \%$ identical to PrtG. The alignment between these polypeptides indicates that the similarity between the deduced protein sequences is not restricted to certain domains but is found throughout the entire length of the molecules. Multiple sequence alignment of PrtW, PrtA, PrtB, PrtC and PrtG revealed two domains that are probably associated with $\mathrm{Ca}^{2+}$ - and $\mathrm{Zn}^{2+}$-binding (Baumann et al., 1993). The $\mathrm{Zn}^{2+}$-binding domain was characterized by a well-defined signature HEXXHXXGXXH (aa 182-192), whereas the $\mathrm{Ca}^{2+}$-binding domain was characterized by the presence of four glycine-rich repeats GGXGXD (aa 339-344, 357-362, 366-371 and 375-380). In contrast, alignment of the amino acid sequence of $\mathrm{PrtW}$ with known proteases from other E. carotovora strains showed that PrtW is clearly distinct: we could not find amino acid sequence similarity between any of these proteases and PrtW (not shown).
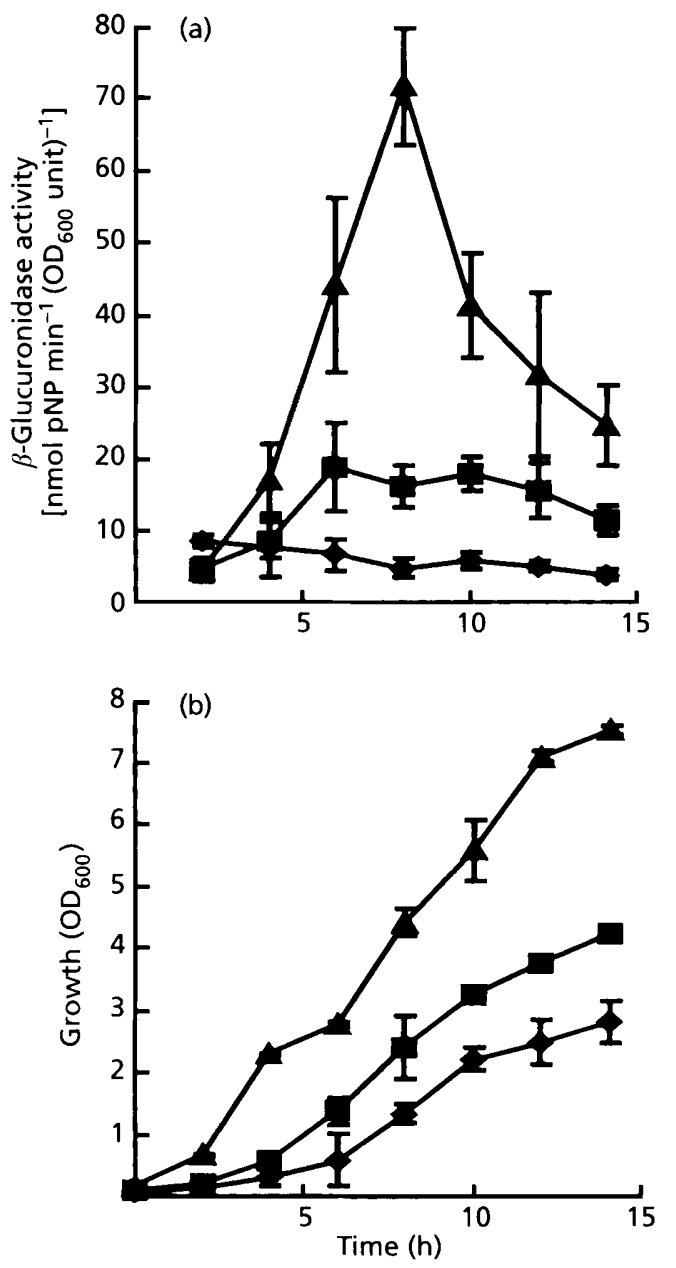

Fig. 2. Expression of the prtW::gusA fusion in strain $\mathrm{SCC} 6004$ under various growth conditions. Cultures were grown in M9 minimal media containing $0.4 \%$ glycerol and supplemented as indicated. (a) $\beta$-Glucuronidase activity measured as a function of time (h) after inoculation; (b) growth of the bacterial cultures followed by measurement of $\mathrm{OD}_{600}$. $\diamond$, Unsupplemented medium; $\mathbf{\square}$, medium plus $16 \%$ celery extract; $\boldsymbol{\Delta}$, medium plus $16 \%$ potato extract.

\section{Expression of the prtw gene}

To obtain clues regarding the role of protease in phytopathogenicity, we constructed a gusA transcriptional fusion to the promoter of the $p r t W$ gene in the mutant strain SCC6004. The prtW::gusA fusion was analysed for $\beta$-glucuronidase synthesis in the absence and presence of plant extract as inducer to test possible induction by plant molecules.

The data shown in Fig. 2 are for cells grown in minimal medium supplemented with celery or potato extract. The effects of potato and celery extracts on prt W::gusA fusion expression were maximal with an extract concentration of $16 \%$. Extracts from both celery and potato showed inducing effects, suggesting that the potential coinducing factor(s) is (are) widely distributed among plant species and tissues. Expression of the prtW : :gusA 
fusion was induced 3- to 4-fold in the presence of celery extract and 17-fold in the presence of potato extract in comparison to the expression of the fusion under uninduced conditions. In these studies, the possibility exists that the difference between potato- and celeryextract-mediated induction rates could result from the different methods used for the preparation of the extracts.

Pirhonen et al. (1991) reported that the level of extracellular enzyme synthesis varies during bacterial growth, being low at the beginning of bacterial growth but starting to accumulate during the exponential growth phase. We found that the expression of $p r t W$, estimated by $\beta$-glucuronidase activity, was also growth-phasedependent. The prtW::gusA fusion was induced maximally during the early exponential growth phase and fell back to the basal levels at the beginning of stationary phase. A similar growth-phase-dependent increase was observed in the protease activity of the wild-type strain SCC3193 (Fig. 3). In conclusion, the maximum synthesis of protease in E. carotovora subsp. carotovora occurs earlier than synthesis of other extracellular enzymes, which usually reach their maximum in the beginning of early stationary phase (Pirhonen et al., 1993).

\section{PrtW expression in different genetic backgrounds}

In order to identify the regulatory genes controlling protease synthesis, we characterized prt $W$ expression in different regulatory mutants of $E$. carotovora subsp. carotovora strain SCC3193. The results show that the prt $\mathrm{W}$ is not expressed in an expl mutant (Fig. 3), demonstrating global regulation of $p r t W$ expression as previously described for pehA, pelB, pelC and celv1 (Pirhonen et al., 1991; Mäe et al., 1995). The protease activity was inhibited by $92 \%$ after addition of $90 \mathrm{mM}$ EDTA, confirming that it was a metalloprotease.

Recently Eriksson et al. (1998) described the global twocomponent regulatory system in E. carotovora subsp. carotovora strain SCC3193. To define the possible role

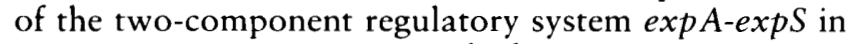
protease expression, we studied protease activity in $\exp A$ and $\exp S$ mutants. A mutation in either of these genes drastically reduced the production of protease (Fig. 3). Taken together, these results show that the $p r t W$ gene expression is regulated by the same global regulatory systems as the other extracellular enzymes involved in virulence. As the expression of the $p r t W$ gene is induced in the presence of plant extracts, the two-

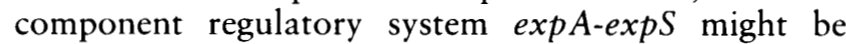
responsible for sensing this signal derived from the host plant extract.

\section{Role of PrtW in phytopathogenicity}

The virulence of the protease mutant was tested in two different plant systems: in isolated plant organs (potato tubers) and in in-vitro-grown tobacco plants (Nicotiana tabacum cv. Samsun). To determine the ability of the
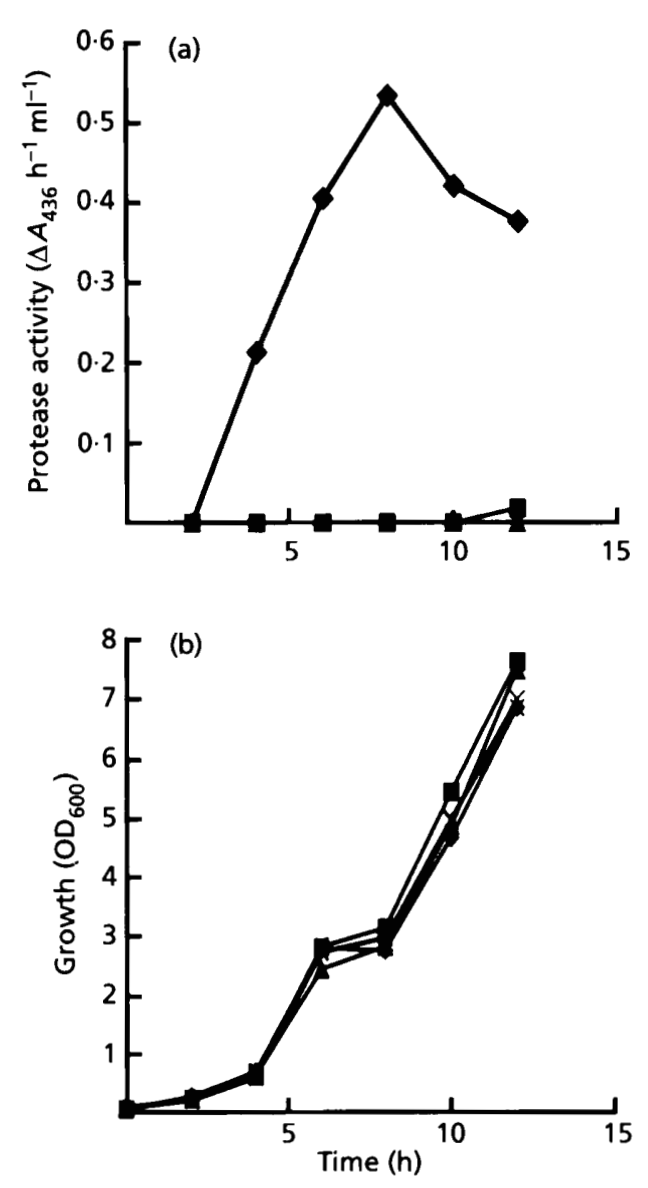

Fig. 3. Growth and protease activity in wild-type and mutant strains. Cultures were grown in M9 minimal media containing $0.4 \%$ glycerol and supplemented with $16 \%$ potato extract. (a) Protease activity measured as a function of time (h) after inoculation; (b) growth of the bacterial cultures followed by measurement of $\mathrm{OD}_{600}$. SCC3193 (wild-type); $\square$, SCC3065 (expl mutant); $\Delta$, SCC3009 (expS mutant); $\times$, SCC3060 (expA mutant); and $\star$, SCC6004 (prtw mutant).

$p r t W$ mutant to induce soft rot, potato tuber maceration experiments were carried out. As the isolated mutant produced normal levels of pectate lyase, polygalacturonase and cellulase (data not shown) any reduction in virulence is a result of loss of protease activity caused by mini-Tn 5 insertion into the $p r t W$ gene (the prt W mutant did not show any residual protease activity).

The virulence of the prtW mutant and of the expl mutant (defective in quorum sensing) was compared with that of the wild-type parent, SCC3193. The results showed that the expI mutant had a markedly reduced capacity to macerate potato tuber tissue, retaining only $10 \%$ of its maceration capacity. The prtW strain still retained about $60 \%$ of its maceration capacity.

The virulence of the prtW mutant was tested by monitoring soft rot symptom development using 2- 
week-old tobacco seedlings. This analysis indicated that $37 \%$ of the plants infected with the prt $W$ mutant did not show any maceration. The remaining $63 \%$ of the infected plants exhibited the normal spreading of softrot symptoms associated with the wild-type strain SCC 3193. Approximately $98 \%$ of plants infected with SCC3193 showed normal disease symptoms. These results suggest that although $\mathrm{PrtW}$ is not essential for pathogenesis, it enhances disease development during the infection process.

\section{DISCUSSION}

\section{PrtW shows similarity to the proteases from E. chrysanthemi}

We employed mini-Tn.5-mediated mutagenesis to isolate new genes of E. carotovora subsp. carotovora that are involved in virulence. The central role of pectolytic enzymes in Erwinia soft rot is well documented (Pirhonen et al., 1991, 1993; Liu et al., 1993). Here, we report the isolation and study of a new gene, prtW, encoding an extracellular protease. The PrtW protease does not show similarity to the previously described proteases from E. carotovora subsp. carotovora (Kyöstiö et al., 1991; Heilbronn et al., 1995). Comparison of the sequence of $\mathrm{PrtW}$ with a range of proteases showed over $60 \%$ identity to PrtB, PrtC, PrtA and PrtG from E. chrysanthemi (Delepelaire \& Wandersman, 1989; Dahler et al., 1990; Ghigo \& Wandersman, 1992a, b). The extensive similarity of PrtW with proteases from E. chrysanthemi indicates a possible common origin of these proteins. Comparison of the amino acid sequence of protease PrtW and proteases produced by $E$. chrysanthemi allowed the tentative identification of sequences essential for $\mathrm{Ca}^{2+}$. binding (aa 182-192) and $\mathrm{Zn}^{2+}$-binding (aa 339-344, $357-362,366-371$ and $375-380$ ) in PrtW. The presence of these specific sequences in PrtW allowed us to categorize the protease from E. carotovora subsp. carotovora strain SCC3193 as a metalloprotease and this was confirmed by its inhibition by EDTA.

\section{Expression of prtW is growth-phase dependent and regulated by global regulatory systems}

Assay of $\beta$-glucuronidase activity from cells harbouring a prt $W:: g u s A$ fusion demonstrated the growth-phasedependent expression of prt W. The level of $p r t W:: g u s A$ activity increased rapidly during the early growth stages and reached peak levels within 6-8 h, during early exponential growth phase (Fig. 2). These findings suggest that the protease gene is responsive to coordinate control by autoinducer and are in agreement with our results showing that prtW is not expressed in an autoinducer-defective expl mutant. The result is in agreement with the recent work of Chatterjee et al. (1995) and Cui et al. (1996). In addition to coordinate control by autoinducer, $\operatorname{PrtW}$ synthesis is also controlled by a two-component regulatory system, expA-expS, described by Eriksson et al. (1998). The other extracellular enzymes produced by SCC3193 were also expressed in a growth-phase-dependent manner, reaching their maxima only in the beginning of stationary phase (Pirhonen et al., 1993). Sequential production of cell-wall-degrading enzymes also occurs in fungal pathogens (Cooper, 1983).

\section{PrtW is involved in virulence in $E$. carotovora subsp. carotovora SCC3193}

The importance of proteases in virulence also seems to differ between various bacterial species. Marker exchange mutants of E. chrysanthemi EC16 defective in production of one or all of the extracellular proteases were not impaired in virulence on plant tissue (Dahler $e t$ al., 1990). Among soft-rot pseudomonads, extracellular protease production correlates more strongly with the ability to macerate plant tissue than does pectolytic enzyme production (Sands \& Hankin, 1975). Tang et al. (1987) reported only slight differences in the virulence of protease-deficient mutants of Xanthomonas campestris pv. campestris on turnip leaves when relatively high inoculum levels were used; at lower inoculum levels, a pronounced reduction in virulence of the protease mutant was observed relative to the wild-type strain. Recently, Shevchik et al. (1998) demonstrated that PrtA and PrtC from E. chrysanthemi were very efficient in processing pectate lyase PelI-2 into PelI-3.

Our results demonstrate that protease activity in E. carotovora subsp. carotovora is necessary for normal progression of disease symptoms. Mutants defective in protease PrtW production exhibited reduced virulence in a potato tuber maceration test. It has been suggested that the expression of virulence by Erwinia spp. involves a fine balance between avoiding the induction of plant defence mechanisms and the rapid killing of plant cells by pectolytic enzymes. Vidal et al. (1997) showed the rapid local induction of pathogenesis-related $(\mathrm{PR})$ genes during the early stages of infection $(4-8 \mathrm{~h}$ after infection). Suppression of these resistance mechanisms is important during the initial stages of infection when the synthesis of virulence factors is not sufficient for the establishment of infection. The expression of the $p r t W$ gene during the early growth phase suggests the possibility that protease might be necessary for suppressing the plant defence response. This effect may be achieved by degradation of host proteins associated with resistance mechanisms. This hypothesis is supported by the work of Heilbronn et al. (1995) who presented data demonstrating in vitro degradation of potato lectin by protease purified from a potato-pathogenic E. carotovora strain.

From the data presented in this report we conclude that we have characterized a new protease from E. carotovora subsp. carotovora with potential importance in plant tissue maceration. This conclusion is supported by the observation that mutation of $p r t W$ in strain SCC3193 reduced maceration virulence by $40 \%$. However it remains unclear what role $\mathrm{PrtW}$ plays in disease development. The presence of protease(s) in many phytopathogenic bacteria suggests a more important 
role in relation to the plant host than previously supposed. These results emphasize the importance of extending the studies on proteases in order to determine their role in virulence.

\section{ACKNOWLEDGEMENTS}

We gratefully acknowledge the critical review and suggestions of Gary D. Lyon in the final preparation of the manuscript. We thank the Estonian Science Fundation (Grant 0230510S98) and European Community (Contract ERBIC15-CT96-0908) for financial support.

\section{REFERENCES}

Ausubel, F. M., Brent, R., Kingston, R. E., Moore, D. D., Seidman, J. G., Smith, J. A. \& Strahl, K. (1987). Current Protocols in Molecular Biology. New York: Wiley.

Bauchop, T. \& Elsden, S.R. (1960). The growth of microorganisms in relation to their energy supply. J Gen Microbiol 23, $457-469$.

Baumann, U., Wu, S., Flaherty, K. M. \& McKay, D. B. (1993). Three-dimensional structure of the alkaline protease of Pseudomonas aeruginosa: a two-domain protein with a calcium binding parallel beta roll motif. EMBO J 12, 3357-3364.

Beaulieu, C., Boccara, M. \& Gijsegem, F. (1993). Pathogenic behaviour of pectinase-defective Erwinia chrysanthemi mutants on different plants. Mol Plant-Microbe Interact 6, 197-202.

Chatterjee, A., Cui, Y., Liu, Y., Dumenyo, C. K. \& Chatterjee, A. (1995). Inactivation of $r s m A$ leads to overproduction of extracellular pectinases, cellulases, and proteases in Erwinia carotovora subsp. carotovora in the absence of the starvation/cell density-sensing signal, $N$-(3-oxohexanoyl)-L-homoserine lactone. Appl Environ Microbiol 61, 1959-1967.

Cooper, R. M. (1983). The mechanisms and significance of enzymatic degradation of host cell wall by parasites. In Biochemical Plant Pathology, pp. 101-135. Edited by J. A. Callow. New York: Wiley.

Cui, Y., Madi, L., Mukherjee, A., Dumenyo, C. K. \& Chatterjee, A. (1996). The RsmA- mutants of Erwinia carotovora subsp. carotovora strain Ecc71 overexpress $h r p N_{E c c}$ and elicit a hypersensitive reaction-like response in tobacco leaves. Mol PlantMicrobe Interact 9, 565-573.

Dahler, G. S., Barras, F. \& Keen, N. T. (1990). Cloning of genes encoding extracellular metalloproteases from Erwinia chrysanthemi EC16. J Bacteriol 172, 5803-5815.

Delepelaire, P. \& Wandersman, C. (1989). Protease secretion by Erwinia chrysanthemi. Protease $\mathrm{B}$ and $\mathrm{C}$ are secreted as zymogens without a signal peptide. J Biol Chem 264, 9083-9089.

Eriksson, A. R. B., Andersson, R. A., Pirhonen, M. \& Palva, E. T. (1998). Two-component regulators involved in the global control of virulence in Erwinia carotovora subsp. carotovora. Mol PlantMicrobe Interact 11, 743-752.

Ghigo, J.-M. \& Wandersman, C. (1992a). Cloning, nucleotide sequence and characterization of the gene encoding the Erwinia chrysathemi B.374 PrtA metalloprotease: a third metalloprotease secreted via a C-terminal secretion signal. Mol Gen Genet 236, 135-144.

Ghigo, J.-M. \& Wandersman, C. (1992b). A fourth metalloprotease gene in Erwinia chrysathemi. Res Microbiol 143, 857-867.

Heilbronn, J. \& Lyon, G. D. (1990). The ineffectuality of potato protease inhibitor on the extracellular protease from Erwinia carotovora subsp. carotovora. J Appl Bacteriol 69, 25-29.
Heilbronn, J., Johnston, D. J., Dunbar, B. \& Lyon, G. (1995). Purification of a metalloprotease produced by Erwinia carotovora spp. and the degradation of potato lectin in vitro. Physiol Mol Plant Physiol 47, 285-292.

Ji, J., Hugouvieux-Cotte-Pattat, N. \& Robert-Baudouy, J. (1987). Use of $\mathrm{Mu}$-lac insertions to study the secretion of pectate lyases by Erwinia chrysanthemi. J Gen Microbiol 133, 793-802.

Jones, S., Yu, B., Bainton, M. \& 11 other authors (1993). The lux autoinducer regulates the production of exoenzyme virulence determinants in Erwinia carotovora and Pseudomonas aeruginosa. EMBO J 12, 2477-2482.

Kelemu, S. \& Collmer, A. (1993). Erwinia chrysanthemi EC16 produces a second set of plant-inducible pectate lyase isozymes. Appl Environ Microbiol 59, 1756-1761.

Kyöstiö, S. R. M., Cramer, C. L. \& Lacy, G. H. (1991). Erwinia carotovora subsp. carotovora extracellular protease: characterization and nucleotide sequence of the gene. $J$ Bacteriol 173, $6537-6546$

Letoffe, S., Delepelaire, P. \& Wandersman, C. (1989). Characterization of a protein inhibitor of extracellular proteases produced by Erwinia chrysanthemi. Mol Microbiol 3, 79-86.

Letoffe, S., Delepelaire, P. \& Wandersman, C. (1990). Protease secretion by Erwinia chrysanthemi: the specific secretion functions are analogous to those of Escherichia coli alphahaemolysin EMBO J 9, 1375-1382.

Liu, Y., Murata, H., Chatterjee, A. \& Chatterjee, A. K. (1993). Characterization of a novel regulatory gene aepA that controls extracellular enzyme production in the phytopathogenic bacterium Erwinia carotovora subsp. carotovora. Mol PlantMicrobe Interact 6, 299-308.

Lojkowska, E., Dorel, C., Reignault, T. P., Hugouvieux-CottePattat, N. \& Robert-Baudouy, J. (1993). Use of GUS fusion to study the expression of Erwinia chrysanthemi pectinase genes during infection of potato tubers. Mol Plant-Microbe Interact 6, $488-494$.

de Lorenzo, V., Herrero, M., Jakubzik, U. \& Timmis, K. T. (1990). Mini-Tn5 transposon derivatives for insertion mutagenesis, promoter probing and chromosomal insertion of cloned DNA in Gram-negative Eubacteria. J Bacteriol 172, 6568-6572.

McMillan, G. P., Barrett, A. M. \& Pérombelon, M. C. M. (1994). An isoelectric focusing study of the effect of methyl-esterified pectic substances on the production of extracellular pectin isoenzymes by soft-rot Erwinia spp. J Appl Bacteriol 77, 175-184.

Măe, A., Heikinheimo, R. \& Palva, E. T. (1995). Structure and regulation of the Erwinia carotovora subspecies carotovora SCC3193 cellulase gene celV1 and the role of cellulase in phytopathogenicity. Mol Gen Genet 247, 17-26.

Maniatis, T., Fritsch, E. F. \& Sambrook, J. (1982). Molecular Cloning: a Laboratory Manual. Cold Spring Harbor, NY : Cold Spring Harbor Laboratory.

Miller, J. H. (1972). Experiments in Molecular Genetics. Cold Spring Harbor, NY: Cold Spring Harbor Laboratory.

Murata, H., McEvoy, J., Chatterjee, A., Collmer, A. \& Chatterjee, A. K. (1991). Molecular cloning of an aepA gene that activates production of extracellular pectolytic, cellulolytic, and proteolytic enzymes in Erwinia carotovora subsp. carotovora. Mol Plant-Microbe Interact 4, 239-246.

Novel, G., Didier-Fichet, M. L. \& Stoeber, F. (1974). Inducibility of $\beta$-glucuronidase in wild-type and hexuronate-negative mutants of Escherichia coli K-12. J Bacteriol 120, 89-95.

Pirhonen, M., Saarilahti, H., Karlsson, M.-B. \& Palva, E. T. (1991). Identification of pathogenicity determinants of Erwinia caro- 
tovora subspecies carotovora by transposon mutagenesis. Mol Plant-Microbe Interact 4, 276-283.

Pirhonen, M., Flego, D., Heikinheimo, R. \& Palva, E. T. (1993). A small diffusible signal molecule is responsible for the global control of virulence and exoenzyme production in plant pathogen Erwinia carotow'ora. EMBO J 12, 2467-2476.

Py, B., Bortoli-German, I., Haiech, I., Chippaux, M. \& Barras, F. (1991). Cellulase EGZ of Erwinia chrysanthemi: structural organization and importance of His 98 and Glu133 residues for catalysis. Protein Eng 4, 325-333.

Sands, D. C. \& Hankin, L. (1975). Ecology and physiology of fluorescent pectolytic pseudomonads. Phytopathology $\mathbf{6 5}$, 921-924.

Sanger, F., Nicklen, S. \& Coulson, A. R. (1977). DNA sequencing with chain-terminating inhibitors. Proc Natl Acad Sci USA 74, 5463-5467.

Shevchik, V. E., Boccara, M., Vedel, R. \& Hugouvieux-Cotte-

Pattat, N. (1998). Processing of the pectate lyase Pell by extracellular protease of Erwinia chrysanthemi 3937. Mol Microbiol 29, 1459-1469.

Tang, J. L., Gough, C. L., Barber, C. E., Dow, J. M. \& Daniels, M. J. (1987). Molecular cloning of protease gene(s) from Xanthomonas campestris pv. campestris: expression in Escherichia coli and role in pathogenicity. Mol Gen Genet 210, 443-448.

Vidal, S., Ponce de León, I., Denecke, J. \& Palva, E. T. (1997). Salicylic acid and the plant pathogen Erwinia carotovora induce defence genes via antagonistic pathways. Plant J 11, 115-123.

Wandersman, C. (1989). Secretion, processing and activation of bacterial extracellular proteases. Mol Microbiol 3, 1825-1831.

Yang, Z., Cramer, C. L. \& Lacy, G. H. (1992). Erwinia carotovora subspecies carotovora pectic enzymes: in planta gene activation and roles in soft-rot pathogenesis. Mol Plant-Microbe Interact 5, 104-112.

Received 17 February 1999; revised 30 April 1999; accepted 11 May 1999. 